\title{
Modified Humic Substances as Soil Conditioners: Laboratory and Field Trials
}

\author{
Natalia A. Kulikova ${ }^{1,2}$, Alexander B. Volikov ${ }^{3}$, Olga I. Filippova ${ }^{1}$, Vladimir A. Kholodov ${ }^{4}$, \\ Nadezhda V. Yaroslavtseva ${ }^{4}$, Yulian R. Farkhodov ${ }^{1,4}$, Anna V. Yudina ${ }^{4}$, , Vitaly A. Roznyatovsky ${ }^{3}$, \\ Yuri K. Grishin ${ }^{3}$, Oral T. Zhilkibayev ${ }^{5,6}$ and Irina V. Perminova ${ }^{3, *}$
}

1 Department of Soil Science, Lomonosov Moscow State University, Leninskiye Gory 1-12, 119991 Moscow, Russia; knat@darvodgeo.ru (N.A.K.); philolga@mail.ru (O.I.F.); yulian.farhodov@yandex.ru (Y.R.F.)

2 Fundamentals of Biotechnology Federal Research Center, Bach Institute of Biochemistry, Russian Academy of Sciences, pr. Leninskiy 33, 119071 Moscow, Russia

3 Department of Chemistry, Lomonosov Moscow State University, Leninskiye Gory 1-3, 119991 Moscow, Russia; ab.volikov@gmail.com (A.B.V.); Vit.Rozn@nmr.chem.msu.su (V.A.R.); grishin@nmr.chem.msu.ru (Y.K.G.)

4 Dokuchaev Soil Science Institute, Pyzhyovskiy Lane 7 Build. 2, 119017 Moscow, Russia; vkholod@mail.ru (V.A.K.); nadezhdayros@gmail.com (N.V.Y.); anna.v.yudina@gmail.com (A.V.Y.)

5 Department of Chemistry, Al Farabi Kazakh National University, 71 al-Farabi Ave., Almaty 050040, Kazakhstan; zhilkibaevoral@mail.ru

6 InterAgroTech LLC, Almaty 050040, Kazakhstan

* Correspondence: iperm@med.chem.msu.ru; Tel.: +7-495-939-55-46

\section{check for}

updates

Citation: Kulikova, N.A.; Volikov, A.B.; Filippova, O.I.; Kholodov, V.A.; Yaroslavtseva, N.V.; Farkhodov, Y.R.; Yudina, A.V.; Roznyatovsky, V.A.; Grishin, Y.K.; Zhilkibayev, O.T.; et al. Modified Humic Substances as Soil Conditioners: Laboratory and Field Trials. Agronomy 2021, 11, 150. https://doi.org/10.3390/agronomy11 010150

Received: 27 December 2020 Accepted: 12 January 2021

Published: 14 January 2021

Publisher's Note: MDPI stays neutral with regard to jurisdictional clai$\mathrm{ms}$ in published maps and institutional affiliations.

Copyright: $\odot 2021$ by the authors. Licensee MDPI, Basel, Switzerland. This article is an open access article distributed under the terms and conditions of the Creative Commons Attribution (CC BY) license (https:// creativecommons.org/licenses/by/ $4.0 /)$.
Abstract: The paper is devoted to the development and performance testing of a soil conditioner based on leonardite humic substances (LHS) modified with 3-aminopropyltriethoxysilane (APTES). The modified HS were obtained by adding APTES to LHS solution at different mass ratios of LHS and APTES, followed by the investigation of siloxane structures using ${ }^{31} \mathrm{Si}$ NMR spectroscopy. The Urbic Technosol was used as a model soil. The size and amount of water-stable soil aggregates were estimated using wet sieving and laser diffraction, respectively. Toxicity was evaluated by monitoring microbial substrate-induced respiration (SIR) and seedling bioassay. Laboratory column experiments demonstrated an increase in water-stability of the 3-5 mm soil aggregates after LHSAPTES application. Field tests showed an increase in the average weighted diameter of micro aggregates (from 59 to $73 \mu \mathrm{m}$ ) and water-stable macroaggregates (from 1.6 to $2.9 \mathrm{~mm}$ ) due to the LHS-APTES amendment. A substantial increase in SIR from 5 to $9 \mathrm{mg} \mathrm{CO}_{2}(\mathrm{~kg} \mathrm{~h})^{-1}$ was detected. Better survival of seedlings was observed. The obtained beneficial results indicate that APTESmodified HS can be successfully used as a soil conditioner. The formation of extended siloxane networks was suggested as the main mechanism of the observed improvement in the structure of the amended soils.

Keywords: water-stable aggregate; soil structure; siloxane; polyelectrolyte complexes; Urbic Technosol

\section{Introduction}

The structure of soil is the basis for its fertility, and aggregate formation is a good indicator of land quality [1,2]. The formation of soil aggregates contributes to water retention capacity, enhances soil aeration, and promotes resilience to degradation due to intensive cultivation [3,4]. The growing anthropogenic impact induces deterioration of the structure of the arable horizon on a large scale [5-7]. Global climate change also has a negative impact on soil aggregation and aggregate stability [8]. As a result, many arable lands face poor structure and dramatically reduced fertility [9]. Urban soils are also affected: They are often characterized by poor structure induced by the disintegration of aggregates. This causes persistent loss of fine materials as fugitive dust, which is a non-point source 
contributor to the particulate matter (PM) load in the atmosphere [10]. The effect of dust is significant and directly affects the population causing health problems, covers crops, stunts their growth [10]. The particles with sizes $<10 \mu \mathrm{m}$ in diameter $\left(\mathrm{PM}_{10}\right)$ can accumulate in the human respiratory tract inducing allergy [11]. Progressive land degradation requires new approaches to the restoration of soil structure.

In nature, water-stable aggregates are formed with the participation of soil organic matter, in particular, humic substances (HS) [12-17]. Reduced content of organic carbon in farmland causes a significant drop in aggregate stability [18]. This is why numerous efforts have been made to use organic waste and commercially available humates as soil conditioners for improving soil structure $[19,20]$. Synthetic polymers served this purpose as well, in particular, water-soluble polyacrylamide (PAM) [21,22]. When applied at the dosage of 1-10 $\mathrm{g} \mathrm{m}^{-2}$ [23], it was shown to prevent soil erosion, while at the dosage of $16 \mathrm{~g} \mathrm{~m}^{-2}$ and higher, it reduced dust emission [24] significantly. The main constraint of a PAM use, however, is the dependence of its efficacy on clay content. The higher the content of clay yielded, the better the results [21]. In addition, it is sensitive to cation valency, e.g., Ca improves PAM efficacy, while Na deteriorates it [21-24]. The most important issue is its toxicity resulting from contamination with acrylamide monomer (AMD). AMD is a neurotoxin and a suspected carcinogen in humans and animals: It causes chromosome damage to mammalian cells in vitro and in vivo [25]. Its uptake by higher plants might result in a negative impact on their growth [26]. Natural degradation rates of PAM are slow, and soil can accumulate PAM in the case of repeated applications [27]. Hence, alternative efficient organic soil conditioners are needed [28].

In our previous studies, we have shown that the use of the silanols-modified HS obtained via covalent bonding of amino organosilanes with humic backbone increased adhesion ability of HS to the surface of clay particles and facilitated the formation of water-stable soil aggregates [29]. Here we propose to use polyelectrolyte complexes of amino organosilanes and HS, which can be synthesized in water by simple mixing (3-aminopropyl-triethoxy)-silane (APTES) and concentrated solution of HS without heating, drying, or using organic solvents. Such a facile synthesis offers substantial advantages while it can be realized on site, immediately before application. In addition, this synthesis meets the principles of green chemistry, as "Green chemistry is the design of chemical products and processes that reduce or eliminate the generation of hazardous substances" (www.epa.gov/greenchemistry).

In this paper, we conducted laboratory and field studies to assess the ameliorating properties of APTES-modified HS onto the structure of poorly structured soil. We used Urbic Technosol [30] as a model. The efficiency of APTES-HS amendments was assessed by measuring the content and size of water-stable aggregates (both macro- and micro aggregates), the content of labile mineral nitrogen, soil respiration activity, and effects on higher plants.

\section{Materials and Methods}

\subsection{Synthesis and Characterization of the Silane-Modified HS}

Commercially available potassium humate (Sakhalin Humates, Russia) isolated from leonardite was used as a parent humic material. It was designated as LHS (C 31.7\%, $\mathrm{H} 2.9 \%, \mathrm{~N} 1.2 \%$, ash $39.8 \%$ ). The data on elemental composition (CHN) were obtained using automatic elemental analyzer Vario EL Cube (Elementar, Germany). Ash content was determined using manual combustion at $800{ }^{\circ} \mathrm{C}$ in the flow of oxygen. 3aminopropyltriethoxysilane (APTES) was of technical grade (Penta Ltd., Russia). It was used as obtained from the producer.

The humic-based conditioner for laboratory-scale experiments was prepared by mixing water solution of leonardite humic substances (LHS) with a required aliquot of APTES and establishing $\mathrm{pH} 8$ by concentrated $\mathrm{HCl}$. The concentration of LHS varied from 0.01 to $10 \mathrm{~g} \mathrm{~L}^{-1}$ depending on the specific experiment. The aliquot of APTES was selected to establish the stoichiometric ratio of carboxyl and amine groups in LHS and APTES, respec- 
tively, as 2:1 and 1:1. The obtained conditioners were designated as LHS-APTES50 and LHS-APTES100, respectively. For a field experiment, only the LHS-APTES100 conditioner was used. For its preparation in the field, $50 \mathrm{~mL}$ of APTES were added to $1000 \mathrm{~mL}$ of $50 \mathrm{~g} \mathrm{~L}^{-1}$ LHS solution, followed by adding $20 \mathrm{~mL}$ of conc. $\mathrm{HCl}$ and adjusting the volume to $5 \mathrm{~L}$. The obtained LHS-APTES solution was applied immediately after preparation.

${ }^{13} \mathrm{C}$ NMR spectra of the HS-silane complexes were recorded using a 5-mm NMR ampoule on an Avance 400 instrument (Bruker, Germany) at an operating frequency of $100 \mathrm{MHz}$ for ${ }^{13} \mathrm{C}$ nuclei using the Carr-Parsell-Maybum-Gill pulsed sequence (CPMG). The spectrum sweep width was $42,735 \mathrm{~Hz}$, the registration time of the free induction decay signal (SSI) was $0.2 \mathrm{~s}$, the time delay between pulse sequences (Td) was $7.8 \mathrm{~s}$, the duration of spectrum acquisition was $12 \mathrm{~h}$. For measurements, a weight of $70 \mathrm{mg}$ of the sample was dissolved in $0.6 \mathrm{~mL}$ of $0.3 \mathrm{M} \mathrm{NaOD}$ in $\mathrm{D}_{2} \mathrm{O} .{ }^{29} \mathrm{Si}$ NMR spectra of the silane-modified HS were recorded on a 400 NMR spectrometer (Agilent, USA). A weight of $100 \mathrm{mg}$ of LHS was dissolved in $10 \mathrm{~mL}$ of $\mathrm{D}_{2} \mathrm{O}(99 \%)$, an aliquot of $100 \mu \mathrm{L}$ of APTES was added and acidified with $1 \mathrm{M} \mathrm{HCl}$ to $\mathrm{pH} 8$. Then, $0.6 \mathrm{~mL}$ of the obtained sample was transferred into a $5 \mathrm{~mm}$ NMR tube. The SSI was $0.027 \mathrm{~s}$, the Td was $0.3 \mathrm{~s}$ at a pulse width of $90^{\circ}$, the spectrum acquisition time was $5 \mathrm{~h}\left(60,000\right.$ scans). Infrared spectra were registered using Nicolet ${ }^{\mathrm{TM}}$ iS50 FTIR spectrometer (ThermoFischer Scientific, USA) in KBr tablets with a resolution of $4 \mathrm{~cm}^{-1}$ and a number of scans of 64 .

\subsection{Sorption Experiments on Silica Gel}

To obtain sorption isotherms, the APTES modified LHS were used at LHS concentrations in the range of 0.1 to $4 \mathrm{~g} \mathrm{~L}^{-1}$ in phosphate buffer (0.03 M, pH 6.0). First, a stock solution of silanol humic derivatives was prepared by adding a weight of APTES (500 mg or $250 \mathrm{mg})$ to $50 \mathrm{~mL}$ of LHS solution $\left(10 \mathrm{~g} \mathrm{~L}^{-1}\right)$ in phosphate buffer $(0.03 \mathrm{M}, \mathrm{pH} 6.0)$ followed by dilution with phosphate buffer $(0.03 \mathrm{M}, \mathrm{pH}$ 6.0) to achieve an LHS concentration of $5 \mathrm{~g} \mathrm{~L}^{-1}$. A weight of APTES $500 \mathrm{mg}$ was used to synthesize LHS-APTES100, and $250 \mathrm{mg}$ was used to synthesize LHS-APTES50. Then, a series of solutions with concentrations ranging from 0.1 to $4 \mathrm{~g} \mathrm{~L}^{-1}$ was prepared by dilution of the stock solution with phosphate buffer $(0.03 \mathrm{M}, \mathrm{pH} 6.0)$. An aliquot $(10 \mathrm{~mL})$ of each solution was added to $0.1 \mathrm{~g}$ of silica gel $\mathrm{SiO}_{2}$. Resulting suspensions were placed into an overhead-shaker for $24 \mathrm{~h}$. Sorption experiments were conducted at room temperature $\left(\mathrm{T}=22 \pm 2{ }^{\circ} \mathrm{C}\right)$ in the presence of air in the daylight. The optical density of the solutions was monitored at $254 \mathrm{~nm}$ using UV-vis spectrometer Cary 50 (Varian Inc., USA) for determining a loss in the concentration of LHS-APTES upon its contact with silica gel. The calibration curves were plotted for each sample used in this study. The amount of LHS-APTES sorbed was calculated as:

$$
q=\frac{\left(C_{0}-C_{W}\right) V}{m}
$$

where: $q$ is the amount of LHS-APTES (g) sorbed onto $1 \mathrm{~g}$ of silica gel, $C_{0}$ and $C_{W}$ are the initial and equilibrium concentration of LHS-APTES in the solution $\left(\mathrm{g} \mathrm{L}^{-1}\right)$, respectively, $V$ is the solution volume (L); $m$ is the mass of silica gel (g).

The obtained isotherms were fitted to the shifted squared modified Langmuir model (SSLM), as described by Grant et al. [31]:

$$
q=\frac{Q_{\max } K \prime\left(C_{W}-C_{S}\right)^{2}}{1+K \prime\left(C_{W}-C_{S}\right)^{2}}
$$

where $q$ is the adsorption $\left(\mathrm{g} \mathrm{g}^{-1}\right), Q_{\max }$ is the maximum adsorption $\left(\mathrm{g} \mathrm{g}^{-1}\right), K^{\prime}$ is the binding constant $\left(\mathrm{L} \mathrm{g}^{-1}\right), C_{W}$ is the equilibrium concertation $\left(\mathrm{g} \mathrm{L}^{-1}\right), C_{S}$ is the shifted concentration $\left(\mathrm{g} \mathrm{L}^{-1}\right)$.

Fitting was performed using the generalized reduced gradient method. The experiments were run in triplicates. 


\subsection{Soil and Its Characteristics}

Both laboratory and field experiments were conducted using the Urbic Technosol (WRB, 2015) located at the Botanical garden of the Lomonosov Moscow State University, Moscow, Russia (55.705895, 37.526701). For the analysis and experiments, the soil was collected from the top $5 \mathrm{~cm}$ layer. The studied soil was silty loam with $\mathrm{pH}$ 7.4. The content of organic $\mathrm{C}$ and total $\mathrm{N}$ was $38 \mathrm{~g} \mathrm{~kg}^{-1}$ and $2.3 \mathrm{~g} \mathrm{~kg}^{-1}$, respectively.

\subsection{Laboratory Experiments with Soil Aggregates}

The LHS-APTES50 and LHS-APTES100 were used as humic-based amendments in laboratory experiments. The LHS solution with the same concentration was used as a control. Soil aggregates with sizes from 3 to $5 \mathrm{~mm}$ were collected by dry sieving of the test soil. The aggregates were placed into a plastic column (inner diameter $3.5 \mathrm{~cm}$, height $15 \mathrm{~cm}$ ) to fill $100 \mathrm{~mL}$ volume. The column was slowly filled with the LHS-APTES50 or LHSAPTES100 solutions by introducing it through the column outlet. This was to remove air between the soil particles and to maximize aggregate saturation. Once the solution of humic amendment reached the top layer of soil, its excess was drained from the column, and the column was left for $24 \mathrm{~h}$. The soil aggregates were then carefully released from the column and left for 7 days until air-dried. The treated aggregates were used for the Andrianov test, as described by Shein et al. [32]. The aggregates were placed in a Petri dish onto filter paper (50 aggregates per dish). The aggregates were capillary saturated by pouring the test solution into a Petri dish by syringe so that it only wetted the filter paper. After that, the aggregates were left for $24 \mathrm{~h}$ until air-dried. A small amount of distilled water was added by syringe just to wet the paper so that the aggregates could be saturated with water capillary forces for $3 \mathrm{~min}$, and only then was water carefully added to half the height of the Petri dish, and counting started for completely slacked aggregates per minute for $10 \mathrm{~min}$. The ratio of water-stable aggregates (WSA) was calculated by the following formula:

$$
K=\frac{\sum_{t=1}^{10}(N-n)\left(\frac{t-1}{10}+0.05\right)+b}{N}
$$

where $t$ is the number of minutes, $n$ is the number of slaked aggregates per minute, $b$ is the number of water-stable aggregates, and $N$ is the total number of aggregates.

The residual aggregates were separated into two parts. One part was placed again in the column and repeatedly (two times) treated with the conditioner solution. Another part was placed into the column and repeatedly (two times) treated with distilled water to test the reversibility of the LHS-APTES sorption. The experiments were run in triplicates.

\subsection{Field Experiments Layout}

The size of the experimental plots was $0.5 \mathrm{~m}^{2}$. Freshly prepared LHS-APTES100 polyelectrolyte complex was introduced as a water solution with a concentration of $10 \mathrm{~g} \mathrm{~L}^{-1}$ at the dosage of $10 \mathrm{~L} \mathrm{~m}^{-2}$. The same amount of either tap water or freshly prepared LHS solution $\left(10 \mathrm{~g} \mathrm{~L}^{-1}\right)$ was applied as the controls for comparison. Overall, five subsequent applications were performed on June 1, 7, 21, 28, and 28 July 2017. The trials were performed in four replicates. The soil was sampled two months after the last treatment from each plot. The "envelope" method was used to collect soil samples: In each plot, four samples were taken in the corners of the plot and one in the center in such a way that when connecting the points with an imaginary line, a picture of a sealed envelope is obtained. To obtain an average sample for each plot, five samples were combined and thoroughly mixed. Sampling was performed using a $50 \mathrm{~mm}$ corer down to a depth of $5 \mathrm{~cm}$. Immediately after sampling, the soil samples were measured for the content of labile ammonium and nitrate. The other parameters: The substrate-induced respiration (SIR), content of WSA, pH, and dissolved organic carbon (DOC) content were measured in the air-dried soil samples. 


\subsection{Water-Stable Aggregates and Micro Aggregates' Assessment}

The content of WSA was determined using the method adapted from [3,33]. In brief, $50 \mathrm{~g}$ of soil was placed in the wetted sieve to wet soil aggregates by capillary forces. This was to avoid the destruction of aggregates by trapped air due to sudden release from the air-dried aggregates upon their contact with water. The prepared soil was then manually wet-sieved by moving the sieve set $(1 \mathrm{~mm}, 0.5 \mathrm{~mm}$, and $0.25 \mathrm{~mm}) 50$ times up and down within $3 \mathrm{~cm}$ depth during $2 \mathrm{~min}$. The collected aggregate fractions were oven-dried at $105^{\circ} \mathrm{C}$ and weighed. The percentage of WSA in the fractions with sizes $>0.25 \mathrm{~mm}$ was calculated based on the mass of initial soil.

The content of water-stable micro aggregates (WSMA) was determined by the laser diffraction technique. The soil sample was dispersed before analysis by suspending soil in distilled water $(2-3 \%)$ and shaking the obtained suspension for $10 \mathrm{~min}$ in a tube shaker Reax top (Heidolph Instruments, Germany) at $2500 \mathrm{rpm}$. The given time and shaking frequency were required for stabilization of soil suspension (the mean weighted diameter of micro aggregates became constant). For particle size analysis (PSA), $30 \mathrm{mg}$ of soil was suspended in $15 \mathrm{~mL}$ of distilled water with the use of an ultrasound dispergator Digital Sonifier S-250D (Branson Ultrasonics, USA) with $\frac{1}{2}$ " Tapped Disruptor Horn at $500 \mathrm{~J} \mathrm{ml}^{-1}$ [34,35]. The obtained suspensions were analyzed using Microtrac Bluewave (Microtrac, USA). The data were analyzed under the assumption that soil particles were absorbing particles (absorption index of 1) of irregular shape [36].

The mean weighted diameter (MWD) was used for the assessment of aggregate stability, while it refers to the size distribution of aggregates, which remained on each sieve after wetting and sieving [37]. The MWD values were calculated for both WSA and WSMA as follows:

$$
M W D=\frac{\sum a_{i} m_{i}}{\sum m_{i}}
$$

where the $a_{i}$ is a mean diameter of the $i$-th fraction (dimensional units are $\mathrm{mm}$ and $\mu \mathrm{m}$ for WSA and WSMA, respectively), the $m_{i}$ is a content of the $i$-th fraction, \%. Four replicates were used for each calculation.

\subsection{Soil Properties}

\subsection{1. $\mathrm{pH}$ Measurements}

A weight of $10 \mathrm{~g}$ of air-dried sieved $(<1 \mathrm{~mm}$ ) soil was placed into a plastic tube, $25 \mathrm{~mL}$ of distilled water was added, then it was shaken on a rotary shaker RM-1M (Elmi, Latvia) for $1 \mathrm{~h}$, and centrifuged at $670 \times \mathrm{g}$ for $5 \mathrm{~min}$. The $\mathrm{pH}$ value of the obtained supernatant was measured using a Hanna Microprocessor $\mathrm{pH}$ Meter $\mathrm{pH} 211$ equipped with a glass electrode HI 1230 (Hanna Instruments Inc., Woonsocket, RI, USA).

\subsubsection{DOC and UV-Vis Measurements}

A weight of $10 \mathrm{~g}$ of air-dried sieved $(<1 \mathrm{~mm})$ soil was placed into a plastic tube, $25 \mathrm{~mL}$ of distilled water was added, then it was shaken on a rotary shaker RM-1M (Elmi, Latvia), and centrifuged at $3000 \times g$ for $10 \mathrm{~min}$ to remove colloidal soil particles from the solution. The DOC content in the obtained water extract was measured using an organic carbon analyzer TOC-L CPN (Shimadzu, Japan). Potassium hydrophthalate was used for calibration. The UV-Vis spectra of the soil extract were recorded using 512 UVVis Spectrophotometer PortLab (PortLab, UK) in a 1-cm quartz cuvette. The absorption coefficient $\mathrm{E} 465^{0.01 \%}$ was measured as an optical density of a solution at the concentration of $0.01 \%$ (wt.) at a wavelength of $465 \mathrm{~nm}$.

\subsubsection{Substrate-Induced Respiration}

Assessment of SIR was carried out according to [38] based on the $\mathrm{CO}_{2}$ production rate. In brief, soil respiration was determined in $50 \mathrm{~mL}$ flasks containing $2 \mathrm{~g}$ of soil wetted to $60 \%$ of the water-holding capacity with distilled water and followed by preincubation for a week at $\mathrm{T}=\left(25 \pm 2{ }^{\circ} \mathrm{C}\right)$. The test flasks were sealed for $12 \mathrm{~h}$, and $\mathrm{CO}_{2}$ 
concentration was measured before and $5 \mathrm{~h}$ after glucose amendment $\left(\sim 56 \mathrm{mmol} \mathrm{kg}{ }^{-1}\right.$ of soil) by sampling $10 \mathrm{~mL}$ of the headspace with a syringe, followed by injection into a gas analyzer DX6210 (RTM, Russia). The results are expressed as a rate of $\mathrm{CO}_{2}$ emission in mg $\mathrm{CO}_{2}(\mathrm{~kg} \mathrm{~h})^{-1}$ and as microbial biomass $\mathrm{Cmic}$ in $\mathrm{mg} \mathrm{kg}^{-1}$ calculated using a rate of $\mathrm{CO}_{2}$ emission according to [38].

\subsubsection{Determination of Labile $\mathrm{NH}_{4}{ }^{+}$and $\mathrm{NO}_{3}{ }^{-}$}

The content of labile $\mathrm{NH}_{4}{ }^{+}$and $\mathrm{NO}_{3}{ }^{-}$was determined in freshly collected samples according to [39]. In brief, a weight of $12 \mathrm{~g}$ of soil was placed into a plastic tube, $25 \mathrm{~mL}$ of $0.25 \mathrm{M} \mathrm{Mg}\left(\mathrm{CH}_{3} \mathrm{COO}\right)_{2}$ was added, then it was placed onto a rotary shaker RM-1M (Elmi, Latvia) for $30 \mathrm{~min}$, and centrifuged at $670 \times \mathrm{g}$ for $5 \mathrm{~min}$. The contents of $\mathrm{NH}_{4}{ }^{+}$and $\mathrm{NO}_{3}{ }^{-}$were determined in the supernatant using ion-selective electrodes ECOM-NH4 and ECOM-NO3, respectively (Econix, Russia). The analysis was performed in four replicates.

\subsection{Bioassay}

Water extracts obtained from the soil samples were tested according to [40]. Wheat seedlings (Triticum aestivum L. var. L1) were used for bioassay, while wheat, a small grain cereal, displays a linear relationship between yield and soil structure characteristics [41]. Ten seeds were placed into a Petri dish filled with $10 \mathrm{~mL}$ of water extracts from the soil samples and left for $72 \mathrm{~h}$ in a thermostat at $24{ }^{\circ} \mathrm{C}$. The shoot and root lengths of seedlings were measured. The experiments were performed in five replicates.

The samples of soils were air-dried, sieved through a $2 \mathrm{~mm}$ sieve, and wetted with distilled water to $70 \%$ of water holding capacity. The germinated wheat seeds were planted into the prepared soil and grown for $30 \mathrm{~d}$ (photoperiod $12 \mathrm{~h}$ light/12 h dark, $200 \mathrm{~lx}$ ). Then the plants were harvested, and the length was measured. Bioassay experiments were performed in four replicates.

\subsection{Statistical data Treatment}

Statistical data treatment was performed using Statistica version 8.0 (StatSoft Inc., Tulsa, OK, USA). A one-way analysis of variance (ANOVA) followed by Duncan's protected least significant difference (LSD) test was applied to examine differences between amendment types at probability level $p=0.05$.

\section{Results}

\subsection{Properties and Sorption Characteristics of the HS-Silane Polyelectrolyte Complexes}

The content of elements in the modified HS (LHS-APTES) with different reagent ratios (on a dry weight basis, \%) is given in Table 1.

Table 1. Some characteristics of element composition of the leonardite humic substances-3aminopropyltriethoxysilane (LHS-APTES) polyelectrolyte complexes with different reagent ratios.

\begin{tabular}{cccccccc}
\hline \multirow{2}{*}{ Sample } & \multicolumn{3}{c}{ Content, \% (wt.) } & \multicolumn{3}{c}{ Atomic Ratio } \\
\cline { 2 - 7 } & C & H & N & Ash & H/C & C/N \\
\hline LHS & 31.7 & 2.9 & 1.2 & 39 & 1.08 & 26 \\
LHS-APTES50 & 31.6 & 3.5 & 2.5 & 43 & 1.34 & 13 \\
LHS-APTES100 & 31.0 & 3.1 & 3.4 & 44 & 1.21 & 9.1 \\
\hline
\end{tabular}

It can be seen that an increase in the APTES amount in the system was accompanied by a gradual increase in the content of nitrogen from $1.2 \%$ in the parent LHS up to $3.4 \%$ in LHS-APTES100. The chemical transformations taking place in the solutions of LHS and APTES included the formation of interpolyelectrolyte complexes due to the interaction of negatively charged carboxyl groups of humic polyanions and positively charged amino groups of APTES and their further polycondensation, as is shown in Figures 1 and 2. They were followed using FTIR, ${ }^{13} \mathrm{C}$, and ${ }^{29} \mathrm{Si}$ NMR spectroscopy (Figure $2 \mathrm{a}-\mathrm{C}$, respectively). 

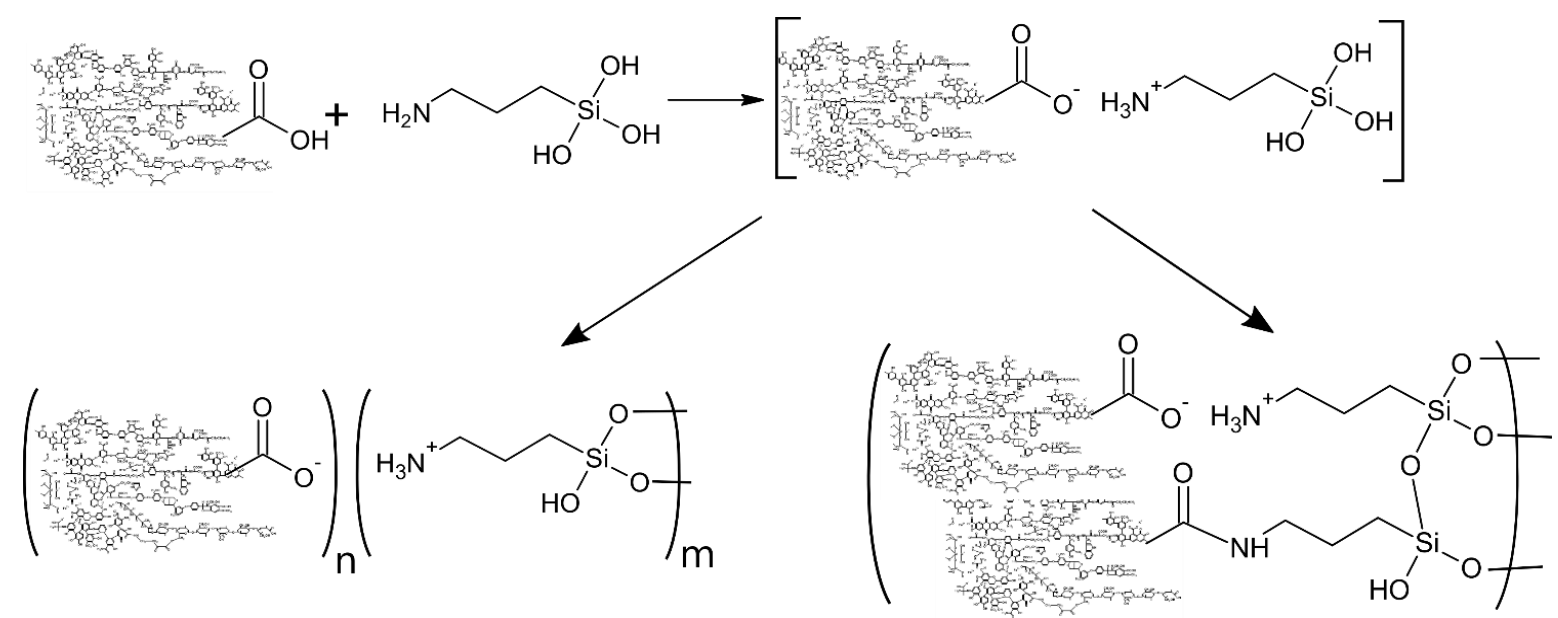

Figure 1. The proposed scheme of interaction of humic substances (HS) with 3-aminopropyltriethoxysilane (APTES) with the formation of HS-silane polyelectrolyte complexes.

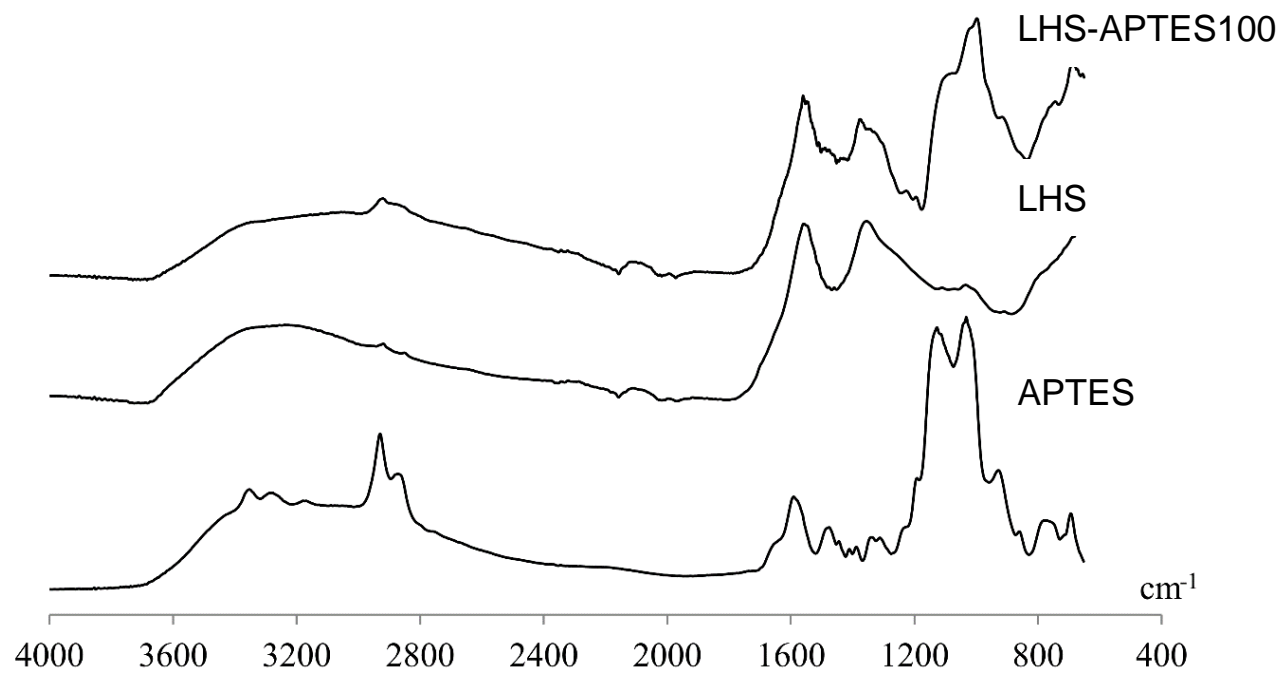

(a)

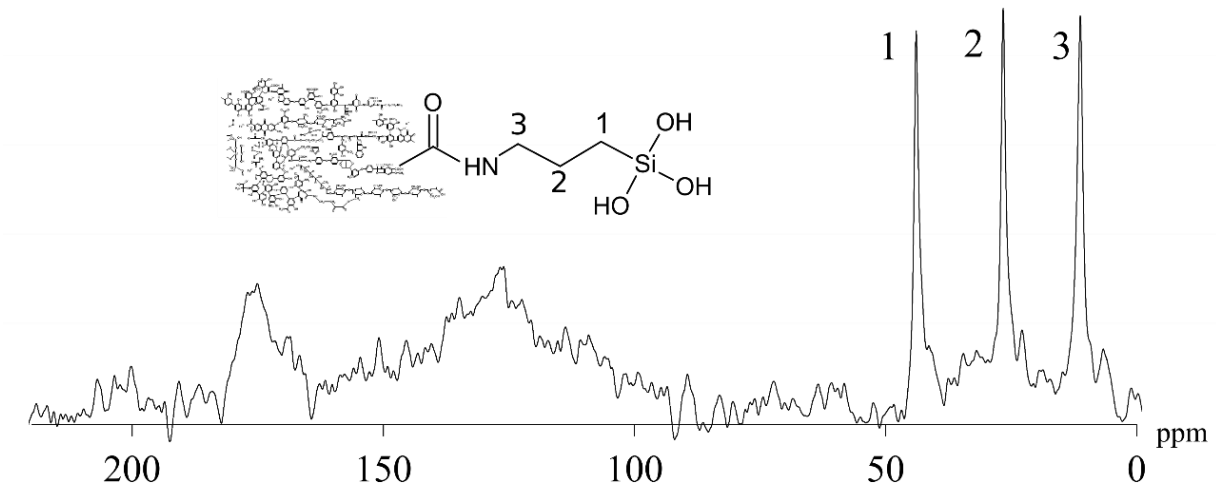

(b)

Figure 2. Cont. 


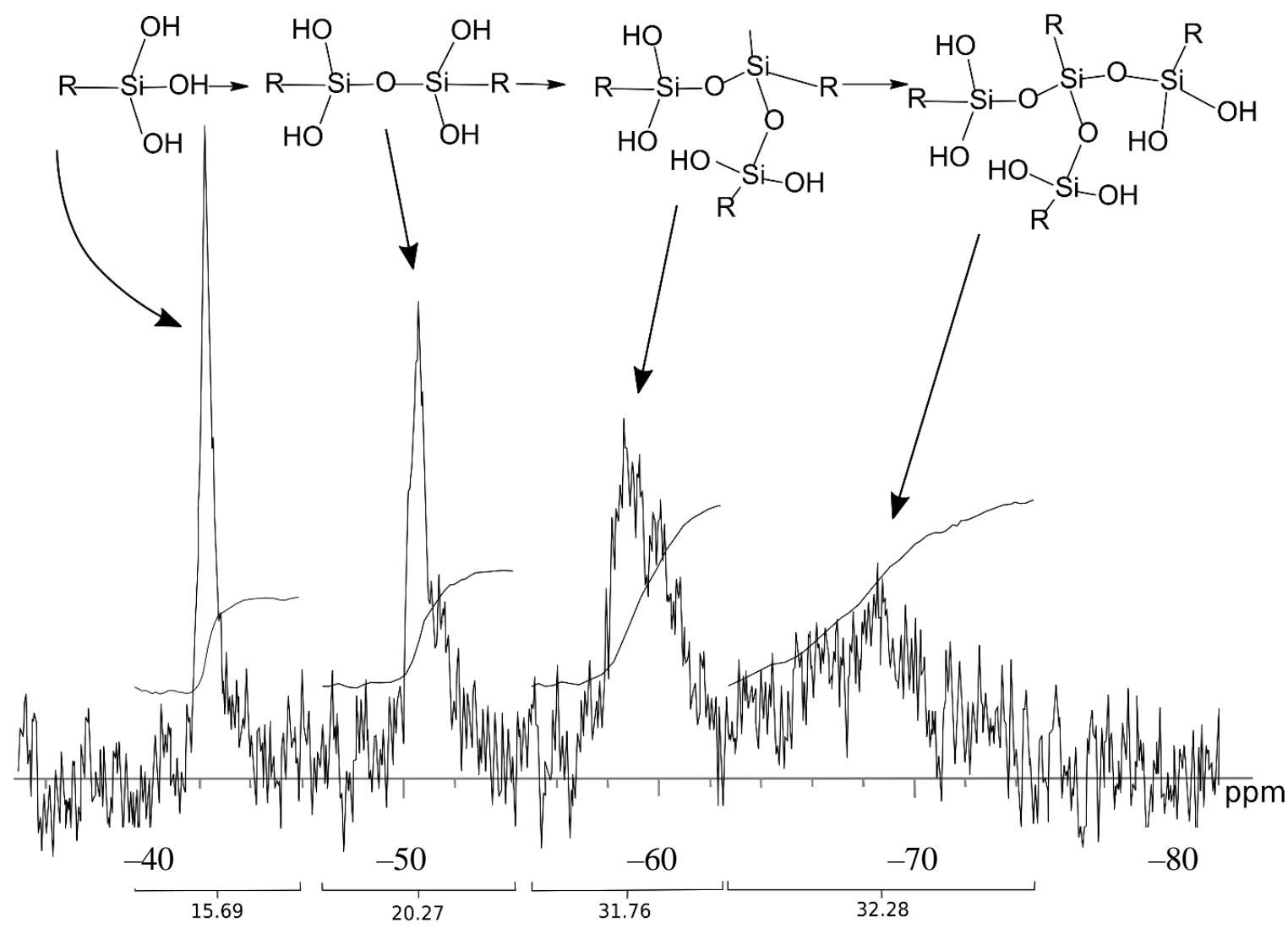

(c)

Figure 2. Spectral characterization of the modified HS: (a) FTIR spectra of leonardite humic substances (LHS)-APTES100, LHS, and APTES; (b) ${ }^{13}$ C NMR spectrum of LHS-APTES100; (c) ${ }^{29}$ Si NMR spectrum of LHS-APTES100.

The FTIR spectrum of the LHS-APTES100, which is the polyelectrolyte complex of LHS and APTES, can be described as a superposition of the spectra of the parent humate LHS and APTES, which is in line with the proposed scheme of its formation (Figure 1). The latter does not imply the formation of new covalent bonds visible to IR spectroscopy. The ${ }^{13} \mathrm{C}$ NMR spectrum showed the presence of propyl-chain of APTES in the reaction product clearly (the corresponding atoms are designated with the numbers 1, 2, 3 in Figure 2b). The ${ }^{29} \mathrm{Si}$ NMR spectrum showed the presence of $\mathrm{Si}$ atoms in the different chemical environments, which were assigned according to [42] as follows (in ppm): silanols 40.5, silane diols in dimers 51, silane diols in chains, rings 58.3, silanetriols (3D oligomers) 68.

For demonstrating adhesive properties of the APTES-modified HS, we ran sorption experiments on the model substrate-silica gel, whose surface is rich in $\mathrm{Si}-\mathrm{OH}$ groups. The results of sorption experiments are shown in Figure 3.

It can be seen that sorption affinity of the LHS + APTES complexes under study was substantially dependent on the LHS:APTES ratio: It was greater for the 1:1 reagent ratio (LHS-APTES100). The same was true for the sorption capacity. Given the S-shape of the obtained isotherms, they were fitted to the shifted squared modified Langmuir model (SSLM) described by Grant et al. [31]. The corresponding parameters are given in Table 2.

From Table 2, it can be deduced that the sorption affinity of the APTES-modified HS with respect to silica gel was proportional to the amount of the incorporated silane modificator. This offers a particular advantage for the use of the LHS-APTES complexes as soil conditioners. To test the feasibility of such an application, we conducted the corresponding laboratory and field studies. 


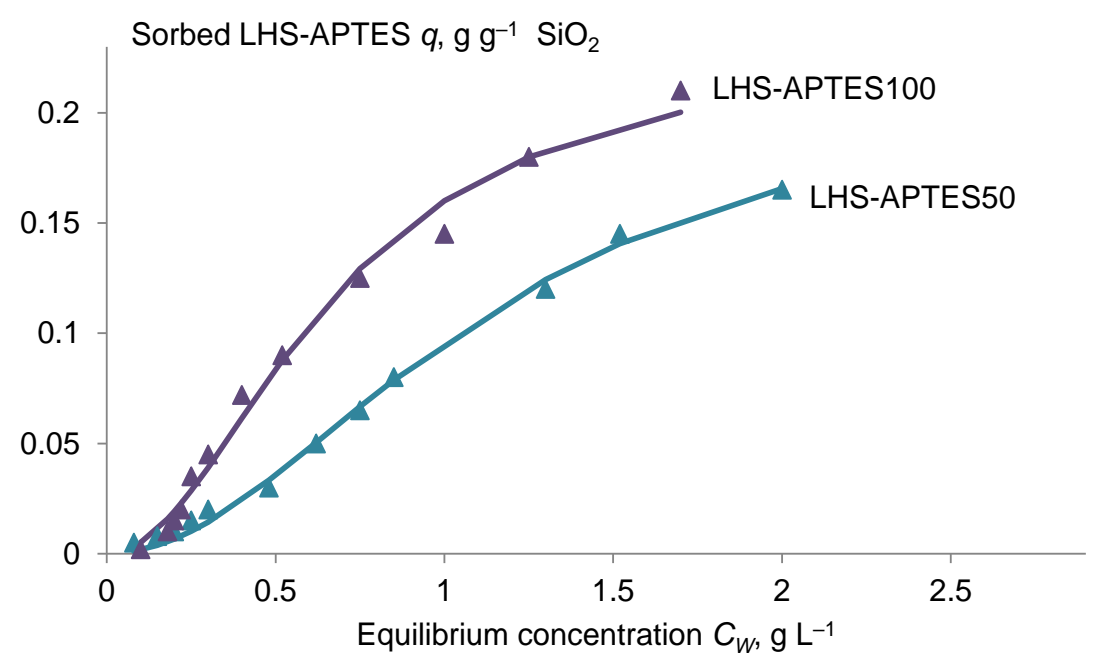

Figure 3. Sorption isotherms of LHS-APTES complexes with different reagent ratio on $\mathrm{SiO}_{2}(0.03 \mathrm{M}$ phosphate buffer, $\mathrm{pH} 6.0,100 \mathrm{mg} \mathrm{SiO} 2,10 \mathrm{~mL}$ volume, $24 \mathrm{~h}, 22{ }^{\circ} \mathrm{C}$ ).

Table 2. Sorption parameters of LHS-APTES polyelectrolyte complexes with different reagent ratio on silica gel fitted to the shifted squared modified Langmuir model (SSLM) (0.03 M phosphate buffer, $\left.\mathrm{pH} 6.0,24 \mathrm{~h}, 20^{\circ} \mathrm{C}\right)$.

\begin{tabular}{ccccc}
\hline Sample & N/C & $Q_{\max }, \mathbf{g ~ g}^{-\mathbf{1}} \mathbf{S i O}_{\mathbf{2}}$ & $\mathbf{K}^{\prime}, \mathbf{L ~ g}^{-\mathbf{1}}$ & $\mathbf{R}^{\mathbf{2}}$ \\
\hline LHS-APTES50 $^{\text {a }}$ & $0.082 \pm 0.007^{\mathrm{a}}$ & $0.22 \pm 0.02^{\mathrm{a}}$ & $78 \pm 6^{\mathrm{a}}$ & 0.996 \\
LHSAPTES100 $^{\mathrm{a}}$ & $0.12 \pm 0.01^{\mathrm{b}}$ & $0.23 \pm 0.02^{\mathrm{a}}$ & $230 \pm 20^{\mathrm{b}}$ & 0.990 \\
\hline
\end{tabular}

The values are means $\pm \mathrm{SD}(n=3)$. The values denoted with different letters within a column are significantly different at $p<0.05$. ${ }^{*} \mathrm{~N} / \mathrm{C}$ is atomic ratio characterizing contribution on APTES into the formed complex

\subsection{Effect of LHS-APTES Complexes on Water-Stable Soil Aggregates: Laboratory Studies}

An increase in the amount of water-stable aggregate tested in this study can be clearly seen as a result of the undertaken treatment with the LHS-APTES amendment (Figure 4).

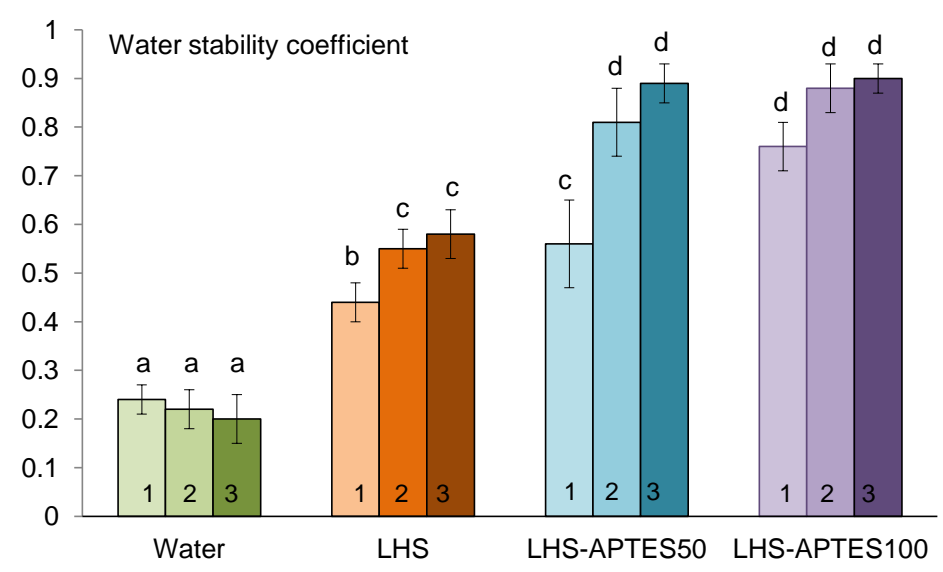

(a)

Figure 4. Cont. 


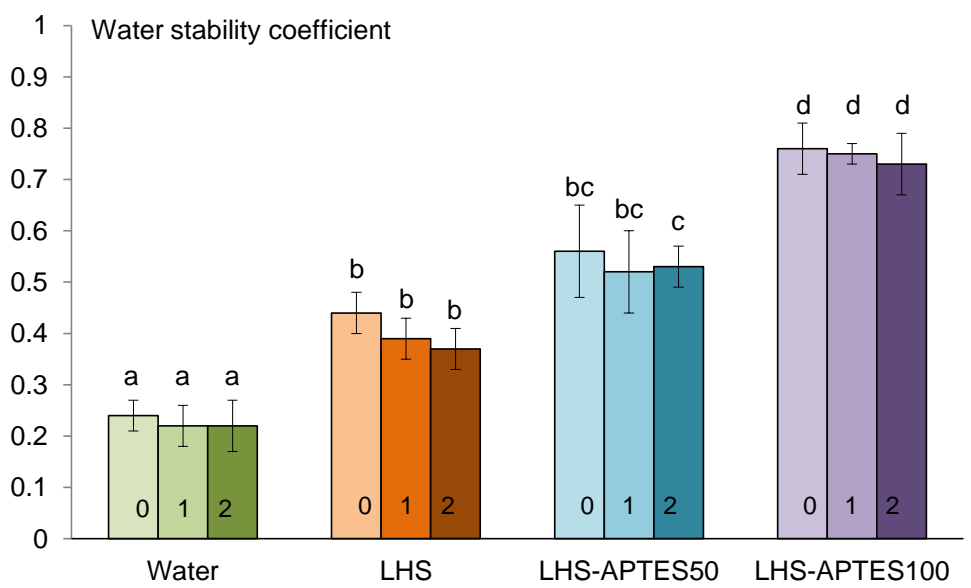

(b)

Figure 4. Water stability coefficient of soil aggregates treated with the LHS-APTES conditioner using three soaking-washing cycles: (a) after three consecutive soaking. The numbers in the columns indicate the soaking steps; (b) after two consecutive washing with water. The numbers in the columns indicate the number of washing steps ( 0 indicates no washing). Error bars represent standard deviation $(n=3)$. Values with different letters are significantly different at $p<0.05$.

After the first application, the highest effect was observed for the LHS-APTES100 reagent; nominally, an increase in the water stability coefficient up to 0.76 was achieved. This value is much higher as compared to the parent humate LHS (0.44) and LHS-APTES50 (0.56). The second and third applications of LHS-APTES50 led to a gradual increase in water resistance up to 0.81 and 0.89 , respectively. In the case of LHS and LHS-APTES100, the second treatment increased the water stability coefficient slightly, and the third one had almost no effect. Washing of the treated aggregates with water desorbed a fairly small amount of the introduced LHS-APTES (Figure 4b). The corresponding calculations demonstrated that only $2 \%$ of the LHS-APTES could be desorbed with water. This is indicative of irreversible sorption of LHS-APTES onto aggregates under laboratory conditions, which may be associated with a large proportion of clay minerals in the soil substrate capable of strong binding to LHS-APTES complexes [43].

The results obtained are promising for the use of LHS-APTES as a soil conditioner. However, they cannot ascertain that the more pronounced desorption of the LHS-APTES will occur under real soil conditions. In addition, it is also impossible to exclude biodegradation of the LHS-APTES. Therefore, the most efficient LHS-APTES100 conditioner was selected for the field trials, which were conducted on the same model poorly structured soil-Urbic Technosol.

\subsection{Effect of the HS-Silane Polyelectrolyte Complexes on Soil Properties: Field Studies}

The differential curves of the micro aggregate size distribution for the soils amended with water, LHS, and LHS-APTES100 are shown in Figure 5.

The amount of larger micro aggregates was substantially increased after treatment with both humic materials, with the most remarkable effect seen for a fraction of 200-600 $\mu \mathrm{m}$ WSMA (Figure 5a). For making out the differences induced in particle size distribution by the APTES-LHS amendment, the difference between the differential size distribution curves of WSMA in soils treated with water, LHS and APTES-LHS, were calculated (Figure 5b). If the curve is positioned above zero on the obtained graphs, it means that the content of WSMA is higher than in the control. On the contrary, if the line is positioned below zero, there are more WSMA of this size in the control soil. For the LHS-APTES conditioner, an increase in the content of WSMA was observed with the formation of the much larger aggregates of about $124 \mu \mathrm{m}$ compared to water and LHS treatments. This is in line with the better adhesive properties and gluing capabilities of LHS-APTES complexes compared 
to non-modified LHS. These very properties of LHS-APTES provided for a drastic increase in the content of WSA, which was not seen with LHS (Table 3).

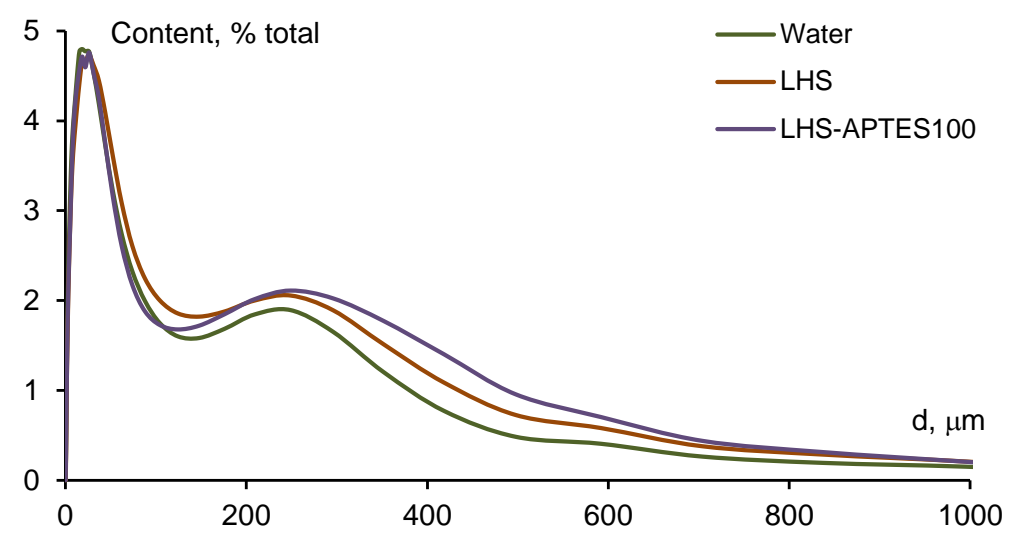

(a)

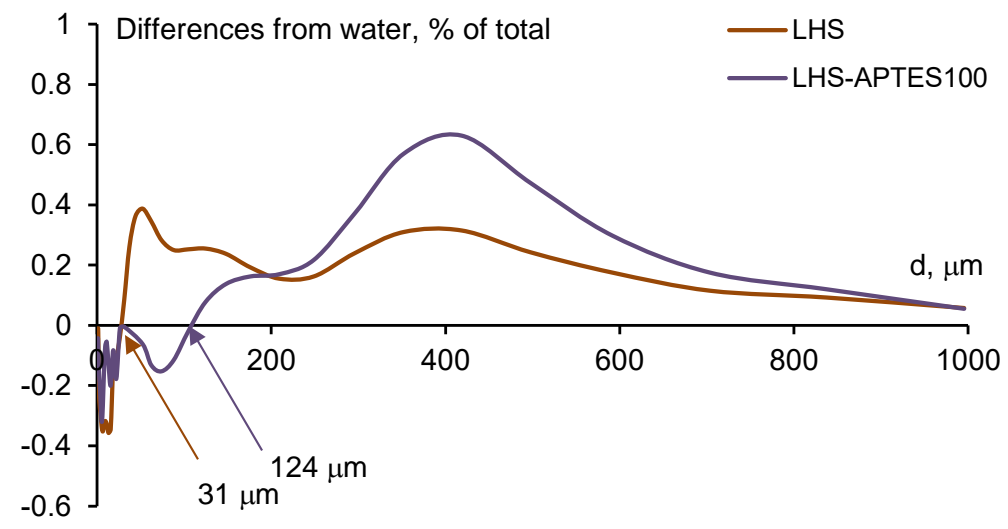

(b)

Figure 5. Particle size distribution curves for micro aggregates in the studied soils two months after five treatments with LHS and LHS-APTES100 under the field experiment conditions: (a) particle size distribution curve; (b) a relative content as compared to the control one.

Table 3. The content and mean-weight diameter (MWD) of water-stable aggregates (WSA) and water-stable micro aggregates (WSMA) in the treated Urbic Technosol.

\begin{tabular}{ccccc}
\hline \multirow{2}{*}{ Treatment } & \multicolumn{2}{c}{ WSA } & \multicolumn{2}{c}{ WSMA } \\
& Content, $\%$ & MWD, mm & Content, \% & MWD, $\mu$ m \\
\hline Water (control) & $86 \pm 3^{\mathrm{a}}$ & $1.6 \pm 0.3^{\mathrm{a}}$ & $8 \pm 1^{\mathrm{a}}$ & $59 \pm 5^{\mathrm{a}}$ \\
LHS & $87 \pm 4^{\mathrm{a}}$ & $1.7 \pm 0.5^{\mathrm{a}}$ & $8 \pm 1^{\mathrm{a}}$ & $70 \pm 14^{\mathrm{b}}$ \\
LHS-APTES100 & $87 \pm 3^{\mathrm{a}}$ & $2.9 \pm 0.5^{\mathrm{b}}$ & $11 \pm 2^{\mathrm{b}}$ & $73 \pm 15^{\mathrm{b}}$
\end{tabular}

The values are means $\pm \mathrm{SD}(n=4)$. The values denoted with different letters within a column are significantly different at $p<0.05$.

The data on the other properties of the treated soil are summarized in Table 4.

Both LHS and APTES-LHS amended soils contained much more labile mineral nitrogen in the form of $\mathrm{NH}_{4}{ }^{+}$as compared to the non-amended soil. This could be explained by partial desorption of the humic amendments from the treated soil, as follows from the DOC measurements in water extracts (Table 4). In general, the observed effects are in line with the data reported by [44], who observed a significant increase in the total $\mathrm{N}$ content in soil after three applications of coal humate at the dosage of $4 \%$. The lower value of E465 ${ }^{0.01 \%}$ measured for DOC from the LHS-APTES100 treated soil could be related to much 
lesser desorption of the introduced humic material. This corroborates well its high sorption efficiency onto mineral surfaces.

Table 4. The properties of soil treated with different amendments.

\begin{tabular}{cccccc}
\hline \multirow{2}{*}{ Treatment } & pH & \multicolumn{2}{c}{ Labile Mineral N, mg kg } & & \multicolumn{2}{c}{ DOC in Water Extract } \\
& & $\mathbf{N H}^{+}$ & $\mathbf{N O}^{+}$ & mg OC kg $^{-1}$ & E465 $^{\mathbf{0 . 0 1 \%}}$ \\
\hline Water (control) & $7.39 \pm 0.08^{\mathrm{a}}$ & $1.5 \pm 0.6^{\mathrm{a}}$ & $2.0 \pm 0.5^{\mathrm{a}}$ & $123 \pm 43^{\mathrm{a}}$ & $0.007 \pm 0.003^{\mathrm{a}}$ \\
LHS & $7.41 \pm 0.07^{\mathrm{a}}$ & $9 \pm 5^{\mathrm{b}}$ & $3 \pm 1^{\mathrm{a}}$ & $200 \pm 80^{\mathrm{ab}}$ & $0.025 \pm 0.009^{\mathrm{c}}$ \\
LHS-APTES100 & $7.4 \pm 0.1^{\mathrm{a}}$ & $12 \pm 5^{\mathrm{b}}$ & $4 \pm 2^{\mathrm{a}}$ & $249 \pm 93^{\mathrm{b}}$ & $0.016 \pm 0.006^{\mathrm{b}}$ \\
\hline
\end{tabular}

Values are means $\pm \mathrm{SD}(n=4)$. Values with different letters within a column are significantly different at $p<0.05$.

\subsection{Biological Effects of the Soil Amendment with HS-Silane Polyelectrolyte Complexes}

Treatment with the APTES-LHS conditioner induced a substantial increase both in the values of SIR and microbial biomass Cmic: from 5 to $9 \mathrm{mg} \mathrm{CO}_{2}(\mathrm{~kg} \mathrm{~h})^{-1}$, and from 211 to $347 \mathrm{mg} \mathrm{kg}^{-1}$, respectively, whereas the parent LHS did not cause any change (Figure 6). This demonstrates the beneficial impact of the LHS-APTES amendment with respect to soil microflora and indirectly indicates the possibility of biodegradation of the LHS-APTES complexes.

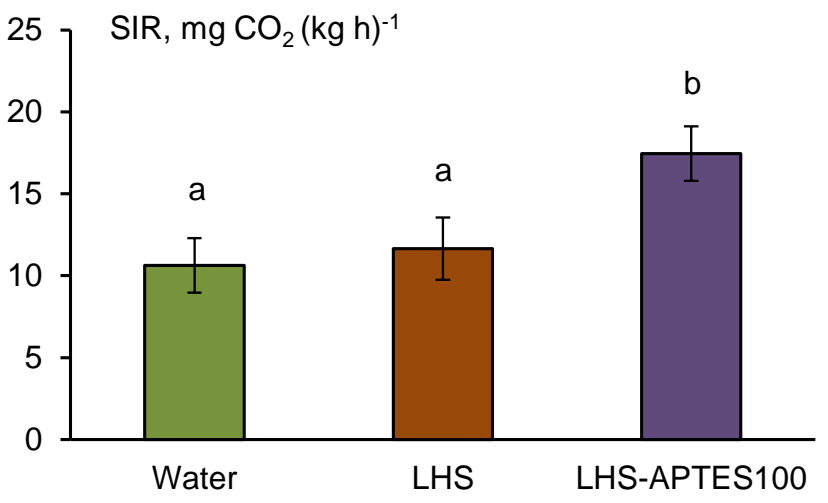

(a)

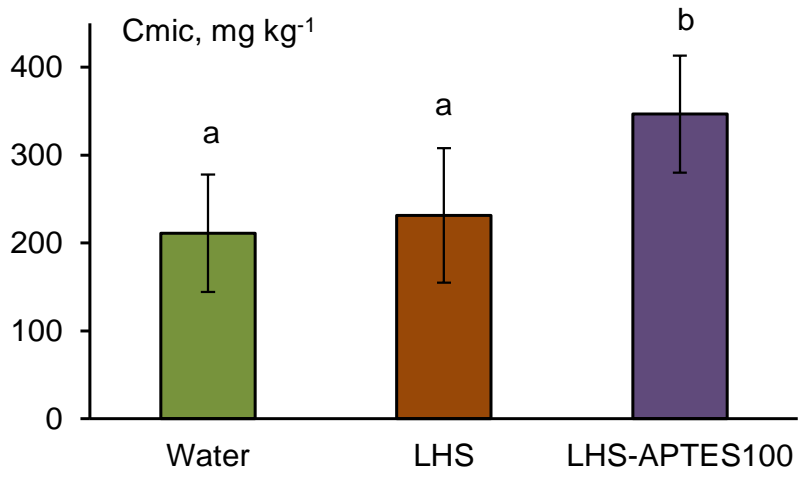

(b)

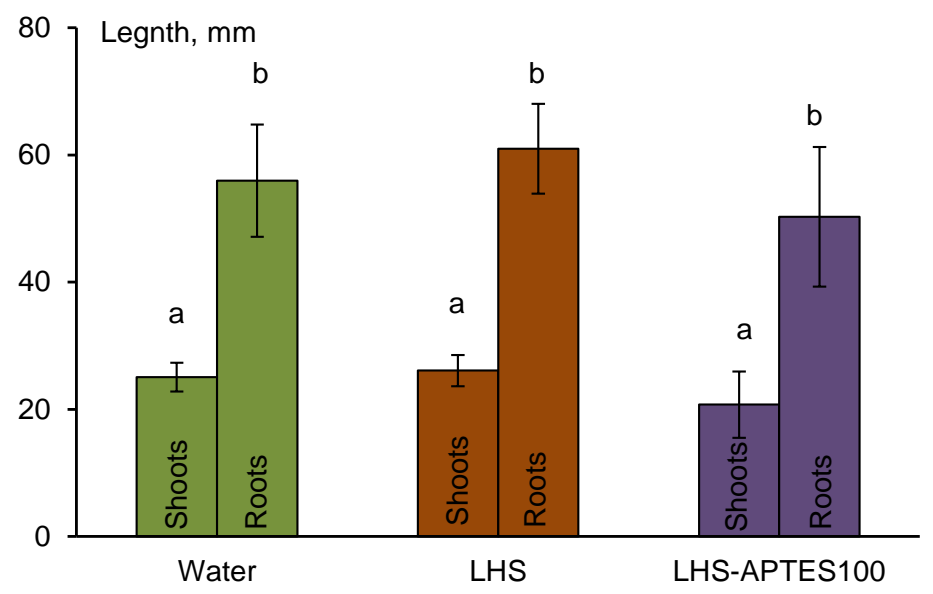

(c)

Figure 6. Cont. 


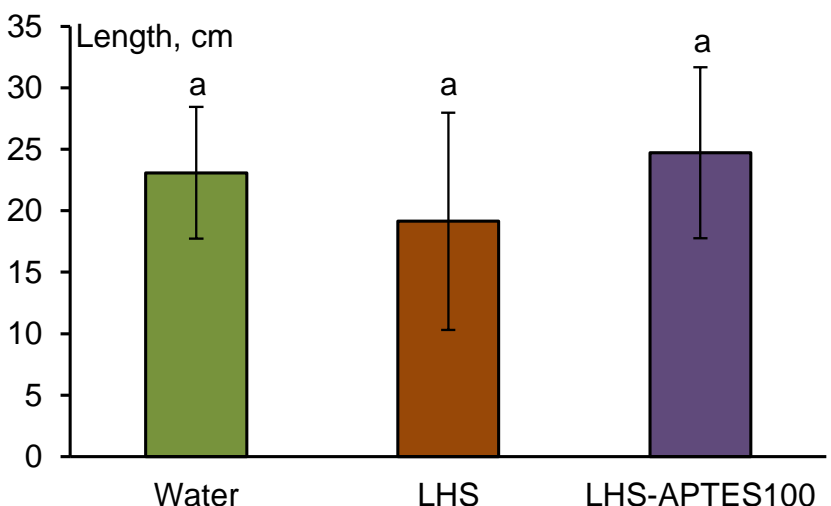

(d)

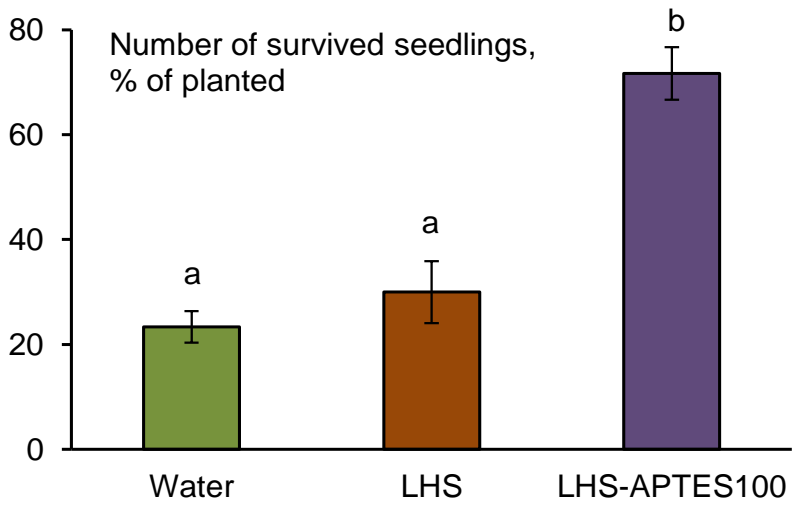

(e)

Figure 6. Biological effects of LHS-APTES amendment in the Urbic Technosol: (a) Effect on the substrate-induced respiration (SIR); (b) Effect of the microbial biomass microbial biomass (Cmic); (c) Effect of the extracted dissolved organic carbon (DOC) on the length of T. aestivum seedlings; (d) Effect on the length of T. aestivum seedlings grown in the amended soils: (e)TEffect on the number of T. aestivum seedlings grown in the amended soils. Error bars represent standard deviations $(n=4)$. Values with different letters are significantly different at $p<0.05$.

Water extracts from the amended soils did not show toxicity with regard to wheat seedlings in the case of both LHS-APTES and LHS. The length of shoots and roots did not differ from the control (Figure 6c). Cultivation of wheat seedlings in the amended soils did not show any harm to plants (Figure 6d). Moreover, a statistically significant $(p<0.05)$ increase in the number of the survived seedlings was demonstrated (Figure 6e) for LHS-APTES, indicating better conditions for plant growth in the amended soil.

\section{Discussion}

\subsection{On Mechanism of Soil Structure Improvement due to the Treatment with LHS-APTES Conditioner}

The ${ }^{29} \mathrm{Si}$ NMR spectrum of LHS-APTES100 showed the presence of Si atoms in the different chemical environments, including silanols, silane diols in dimers, silane diols in chains and rings, and silanetriols (Figure 2c). The corresponding integral values (in \% $\mathrm{Si}$ ) were 15.7, 20.3, 31.8, and 32.2, respectively. The obtained values are in good agreement with the literature data on the existence of APTES in dilute aqueous solutions (in \%): 12, 20,32, and 36 [42]. This is indicative of merely accelerating role of HS in the condensation of silanetriols: It facilitates the opening of the cyclic structure of the hydrolyzed APTES in water solution, but it does not interfere with the condensation process of silanetriols, with the amount, type, and ratio of the condensed species. These species connect, forming a highly branched bifunctional network: on one side, it carries positively charged $-\mathrm{NH}_{3}{ }^{+}$ groups, which produce multiple ionic bonds with negatively charged carboxyl groups of humic polyanions yielding strongly bound interpolyelectrolyte complexes, as described in [43]. On the other side, the silsesquioxane network has multiple active silanol groups, which are capable of formation of intermolecular siloxane bonding as well as covalent bonding to $\mathrm{SiOH}$ carrying surfaces (e.g., sand, clay, silica gel). Hence, these silsesquioxane networks might serve as linkers between humic materials and soil particles by producing self-assembled adlayers onto their surface.

The APTES-modified HS had a high affinity for sorption onto Si-OH carrying surfaces leading to self-assembly of humic adlayers at the water-solid interface. This is indicative of the decisive role of silanol groups in the adhesive affinity of the LHS-APTES complexes. The maximum sorption capacity of LHS-APTES on $\mathrm{SiO}_{2}$ obtained in this study reached $230 \mathrm{mg} \mathrm{g}^{-1}$. This value is comparable to the high-end content of organic carbon in the most fertile humus-rich soils, such as Mollisol [45]. It should be noted that this value is also close to those reported in our previous experiments for the thermally cured silanol derivatives [46]. This is important because the preparation of the LHS-APTES conditioner 
occurs in water and does not imply energy-consuming thermal treatment. The driving mechanism of self-assembly of the APTES-modified HS onto the water-solid interface is the formation of covalent $\mathrm{Si}-\mathrm{O}-\mathrm{Si}$ bonds between the silanols incorporated into the humic matrix and the silanols on the mineral surface (or other $\mathrm{OH}$-carrying substrate, such as silica gel), which is schematically shown in Figure 7.

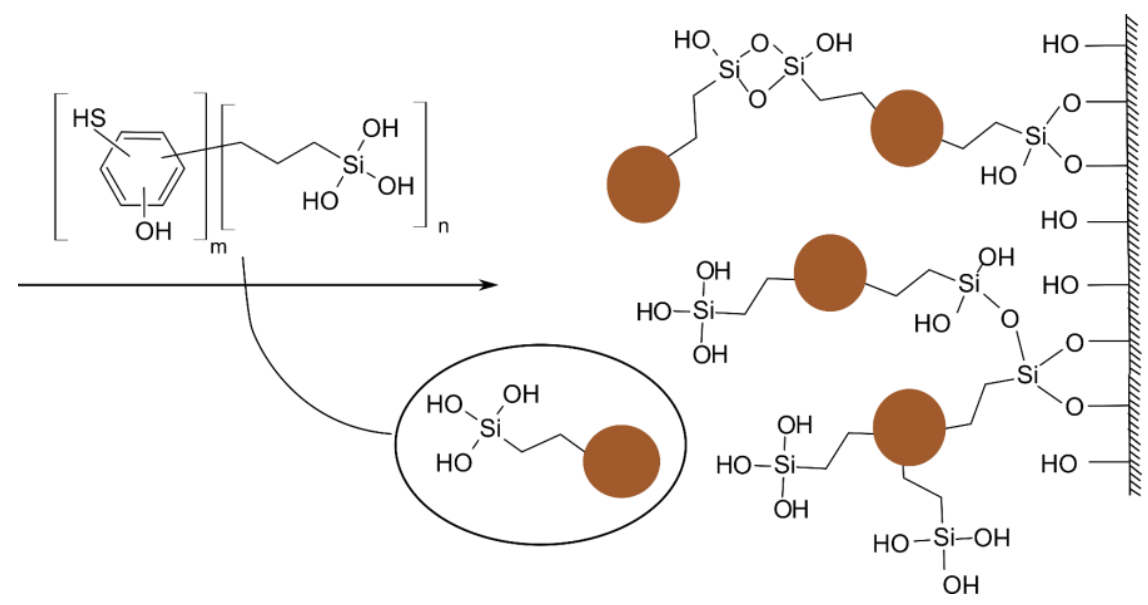

Figure 7. Schematic interaction of the silanol-rich modified HS with Si-OH-carrying solid phase.

Given the high content of hydrophobic aromatic structures in the leonardite humate used in this study, the formation of humic adlayer on the Si-OH surfaces increased its hydrophobicity. This was experimentally demonstrated in our previous studies for the glass surface coated with the adlayer of the cured silanol-HS derivatives [43]. In its turn, an increase in hydrophobicity of mineral surfaces is important for improving the water resistance of soil due to a decrease in wettability [14,47]. Our further experiments with soil macroaggregates showed a drastic increase (a factor of two) in water-resistance of aggregates treated with the APTES modified HS. In addition, no desorption of organic matter was observed from the treated aggregates. This allowed us to propose the mechanism of the observed increase in aggregate stability on account of both factors: formation of siloxane bonds and wettability decrease of organics-coated mineral surfaces. The scheme of action of the APTES-modified HS onto soil particles is shown in Figure 8.

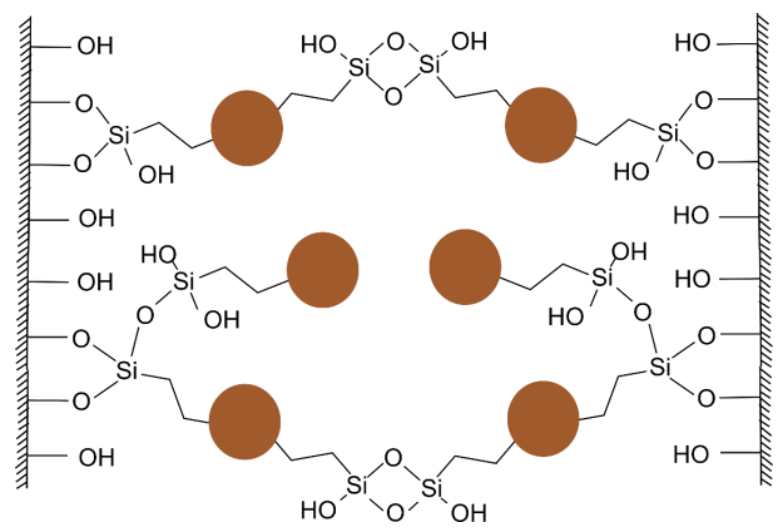

Figure 8. Interplay of two types of interactions, which provide for the efficiency of the APTE-modified HS as soil conditioner: adhesion due to formation of siloxane bonds and a decrease in wettability due to immobilization of hydrophobic, aromatics-rich domains of coal HS (shown as brown rings).

The field experiments demonstrated beneficial effects of the silanol-rich modified HS on both the micro aggregate and macroaggregate level: introduction of LHS-APTES increased both content and diameter of WSMA (Table 3). The higher percentage of larger aggregates found in the amended soil is indicative of the enhanced binding of smaller par- 
ticles into aggregates of sizes from 100 to $1000 \mu \mathrm{m}$ induced by the LHS-APTES amendment. This in situ integration was induced by both the propagation of intermolecular siloxane bonding of APTES modified HS and immobilization of hydrophobic humic domains on the mineral particles (e.g., clays) reinforcing interparticle contacts. The obtained effects are in line with the classification of organic binding agents proposed by Tisdall and Oades [13], who considered hydrophobic aromatic humic materials as "persistent" binding agents contributing the most to the formation of micro aggregates. The hydrophobic components of bound humic molecules reduce water infiltration and increase macroaggregate stability [48-51]. This effect was achieved in this study by binding leonardite humic materials to soil particles via siloxane linkers. The APTES modified LHS was a much stronger inductor of water-stable aggregate formation as compared to the parent humate (LHS).

The demonstrated capability of the modified HS to glue together micro aggregates with sizes $<124 \mu \mathrm{m}$ into the larger ones (Figure 5) is of particular interest for protecting micro aggregates from wind erosion. Cultivated soils tend to lose small particles (up to $50 \mu \mathrm{m}$ ) due to wind blow-out during tillage operations [52]. The highest emission occurs for particles (PM) under $10 \mu \mathrm{m}$ [53], which makes soils an important source of this dangerous air pollutant $[54,55]$. Once inhaled, $\mathrm{PM}$ with sizes $<10 \mu \mathrm{m}\left(\mathrm{PM}_{10}\right)$ can penetrate deep into the lungs and thus, pose a risk to human health [56]. PM control is of particular concern on the exposed ground in urban areas [11]. The high efficiency for dust suppression was recently reported for the humic-like material-modified lignosulfonate [57]. Low cost, good water solubility, nontoxicity, and biodegradability were listed as the main benefits of this product. At present, non-modified lignosulfonate is one of the most frequently used dust suppressants in Sweden [11]. Our data demonstrated that the introduction of non-modified humic material into the soil decreased the content of WSMA with sizes less than $31 \mu \mathrm{m}$, whereas, for the APTES-modified HS, it reached $124 \mu \mathrm{m}$ (Figure 5b). Therefore, the superior adhesive properties of the silanol-rich modified HS with regard to mineral particles are very promising for their application as dust suppressants. However, a primary concern of lignosulfonate use is the high water solubility causing its leaching from the roadbed during heavy rains, making frequent reapplication necessary [11]. In this study, the treatment with the modified HS has increased the DOC content by a factor of two compared to the untreated soil, while in the case of the parent humate (LHS), an increase in DOC was not so significant. (Table 4). This may indicate partial desorption of both the LHS and LHS-APTES100 from the soil particles in the field. Nevertheless, a strong growth in the absorption coefficient $\left(\mathrm{E} 465^{0.01 \%}\right.$ ) was observed from 0.007 to 0.025 for DOC extracted from LHS treated soil. Rather, such high values are typical for alkali extracted HS than for soil DOC. This might be indicative of partial desorption of the strongly colored coal humate [58]. Significantly smaller values found for the DOC extracted from the soil amended with the modified HS did not allow us to draw unambiguous conclusions about the nature of the desorbed materials, and more detailed study on the interaction of the APTES modified HS with soil particles in the field is needed. Another unresolved issue on the use of the APTEs-modified HS is the unknown biodegradation rate. Both issues should be considered upon the development of soil restoration technologies with the use of the APTES-modified HS as a soil conditioner.

\subsection{Biological Effects of the Modified HS Used in This Study}

APTES-modified HS caused an increased concentration of ammonium nitrogen in the treated soil (Table 4), leading to the enhanced values of SIR and microbial biomass. At the same time, the parent humate (LHS) did not produce similar effects (Figure 6a,b). Besides, only LHS-APTES100 introduction resulted in an increase in macroaggregate size, whereas LHS did not (Table 3). This finding corroborates well the data on the preferable accumulation of microbial biomass within macroaggregates compared to micro aggregates [59] and the existence of a positive correlation between the amount of macroaggregates and microbial biomass [60]. The formation of macroaggregates results in the higher availability of organic matter, improves chemical and physical soil properties providing 
protection to the habitats of microorganisms that contribute to enhanced levels of microbial biomass in these systems [61]. An increase in SIR and microbial biomass observed in this study for the APTES-modified HS (Figure 6a,b) could be related to improved soil structure on the level of macroaggregates (Figure 5, Table 3). Furthermore, our previous long-term (78 days) laboratory experiments demonstrated that the APTES-HS complexes could be a source of slow-release nitrogen in the form of ammonia, followed by its conversion into nitrates [39]. It would be of interest to follow the influence of APTES-modified HS on the activity of soil autotrophic bacteria involved in nitrification, e.g., Nitrosomonas, Nitrobacter. We could also relate the observed increase in SIR in the presence of the LHS-APTES to its biodegradation. However, more research on this issue is needed.

The modified HS used in this study did not cause any inhibitory effect on the growth of wheat seedlings: The seedling length did not differ from the control (Figure 6c-e). It is indicative of the ecological safety of the modified HS for soil applications. Moreover, the cultivation of wheat plants in the soil amended with the modified HS showed a much higher survival rate (threefold) of the seedlings compared to the control (Figure 6e). The better seedling survival might be connected to more favorable physical properties of soil, nominally, to an increase in a WSA diameter. It is known that the aggregation of soil particles improves conditions for plant growth $[38,41]$. This is why the capability of restoring good soil structure is the most important criteria for an efficient soil conditioner.

\section{Conclusions}

The results of both laboratory and field studies showed beneficial effects of the treatment of poorly structured soil with the modified HS, which caused an improvement in the soil structure both on the level of macro- and micro aggregates. We suggest that the main reason for the good ameliorating properties of the APTES modified HS is the efficient incorporation of hydrophobic domains of leonardite humic materials into the soil organo-mineral matrix by strong siloxane bonding to soil minerals. This contributed to the elevated hydrophobic character of organic matter of the amended soil, reduced infiltration, and improved water stability of soil aggregates. As a result, the use of the modified HS for treatment of the model poorly structured soil (Urbic Technosol) led to an improvement in its aggregation state. In addition, we observed a lack of inhibiting activity with respect to soil microbiota and wheat plants in application rates up to $5 \mathrm{~g} \mathrm{~m}^{-2}$. The obtained results allow us to conclude that the APTES-modified HS can be considered as an efficient and ecologically safe soil conditioner, which can be applied for restoring degraded soils.

Author Contributions: Conceptualization, N.A.K., A.B.V., V.A.K., and I.V.P.; methodology, I.V.P., A.B.V., and V.A.K.; formal analysis, N.A.K., A.B.V., O.I.F., and V.A.K.; investigation, N.A.K., A.B.V., O.I.F., V.A.K., N.V.Y., Y.R.F., A.V.Y., V.A.R., Y.K.G., and O.T.Z.; resources, N.A.K., V.A.K., and I.V.P.; writing-original draft preparation, N.A.K., A.B.V., V.A.K., and I.V.P.; writing-review \& editing, N.A.K. and I.V.P.; visualization, N.A.K. and A.B.V.; supervision, N.A.K., V.A.K., and I.V.P.; funding acquisition, I.V.P. All authors have read and agreed to the published version of the manuscript.

Funding: This research was funded by the RUSSIAN FOUNDATION FOR BASIC RESEARCH, grant number 18-29-25065 (in part of synthesis and characterization of APTES-HS complexes) and the RUSSIAN SCIENCE FOUNDATION, grant number 16-14-00167 (in part of laboratory and field studies on ameliorating properties of APTES-HS complexes).

Institutional Review Board Statement: Not applicable.

Informed Consent Statement: Not applicable.

Data Availability Statement: Triticum aestivum L. plants were used in this study. L1 cultivar (Russian State Agrarian University, Moscow Timiryazev Agricultural Academy) was kindly provided by Dr. S.V. Zhelezova (Russian State Agrarian University, Moscow Timiryazev Agricultural Academy).

Acknowledgments: This study involved the facilities of the Center for Collective Use "Functions and properties of soil and soil cover" of the Dokuchaev Soil Institute.

Conflicts of Interest: The authors declare no conflict of interest. 


\section{References}

1. Dexter, A.R.; Czyż, E.A. Applications of S-theory in the study of soil physical degradation and its consequences. Land Degrad. Dev. 2007, 18, 369-381. [CrossRef]

2. Loss, A.; Pereira, M.G.; Costa, E.M.; Beutler, S.J. Soil fertility, physical and chemical organic matter fractions, natural C-13 and N-15 abundance in biogenic and physicogenic aggregates in areas under different land use systems. Soil Res. 2014, 52, 685-697. [CrossRef]

3. Six, J.; Paustian, K.; Elliott, E.T.; Combrink, C. Soil structure and organic matter: I. Distribution of aggregate-size classes and aggregate-associated carbon. Soil Sci. Soc. Am. J. 2000, 64, 681-689. [CrossRef]

4. Bieganowski, A.; Zaleski, T.; Kajdas, B.; Sochan, A.; Józefowska, A.; Beczek, M.; Lipiec, J.; Turski, M.; Ryżak, M. An improved method for determination of aggregate stability using laser diffraction. Land Degrad. Dev. 2018, 29, 1376-1384. [CrossRef]

5. Larney, F.J.; Angers, D.A. The role of organic amendments in soil reclamation: A review. Can. J. Soil Sci. 2012, 92, 19-38. [CrossRef]

6. Dong, X.; Guan, T.; Li, G.; Lin, Q.; Zhao, X. Long-term effects of biochar amount on the content and composition of organic matter in soil aggregates under field conditions. J. Soils Sediments 2016, 16, 1481-1497. [CrossRef]

7. Sharifi, Z.; Azadi, N.; Certini, G. Fire and tillage as degrading factors of soil structure in Northern Zagros Oak Forest, West Iran. Land Degrad. Dev. 2016, 28, 1068-1077. [CrossRef]

8. Wang, Y.; Gao, S.; Li, C.; Zhang, J.; Wang, L. Effects of temperature on soil organic carbon fractions contents, aggregate stability and structural characteristics of humic substances in a Mollisol. J. Soils Sediments 2016, 16, 1849-1857. [CrossRef]

9. Kraaijvanger, R.; Veldkamp, T. Grain productivity, fertilizer response and nutrient balance of farming systems in Tigray, Ethiopia: A multiperspective view in relation to soil fertility degradation. Land Degrad. Dev. 2014, 26, 701-710. [CrossRef]

10. Grimmond, S. Urbanization and global environmental change: Local effects of urban warming. Geogr. J. 2007, 173, 83-88. [CrossRef]

11. Edvardsson, K. Gravel roads and dust suppression. Road Mater. Pavement Des. 2009, 10, 439-469. [CrossRef]

12. Kononova, M.M. Soil Organic Matter: Its Nature, Its Role in Soil Formation and in Soil Fertility, 2nd ed.; Pergamon Press: Oxford, UK, 1966; pp. 1-544.

13. Tisdall, J.M.; Oades, J.M. Organic matter and water stable aggregates in soils. J. Soil Sci. 1982, 33, 141-163. [CrossRef]

14. Piccolo, A.; Pietramellara, G.; Mbagwu, J.S.C. Use of humic substances as soil conditioners to increase aggregate stability. Geoderma 1997, 75, 267-277. [CrossRef]

15. Lugato, E.; Simonetti, G.; Morari, F.; Nardi, S.; Berti, A.; Giardini, L. Distribution of organic and humic carbon in wet-sieved aggregates of different soils under long-term fertilization experiment. Geoderma 2010, 157, 80-85. [CrossRef]

16. Jin, X.; An, T.; Gall, A.R.; Li, S.; Sun, L.; Pei, J.; Gao, X.; He, X.; Fu, S.; Ding, X.; et al. Long-term plastic film mulching and fertilization treatments changed the annual distribution of residual maize straw $\mathrm{C}$ in soil aggregates under field conditions: Characterization by 13C tracing. J. Soils Sediments 2018, 18, 169-178. [CrossRef]

17. Mitran, T.; Mani, P.K.; Bandyopadhyay, P.K.; Basak, N. Influence of organic amendments on soil physical attributes and aggregate associated phosphorus under long-term rice-wheat cropping. Pedosphere 2018, 28, 823-832. [CrossRef]

18. Ozgöz, E.; Günal, H.; Acir, N.; Gökmen, F.; Birol, M.; Budak, M. Soil quality and spatil variability assessment of land use effects in a Typic Haplustoll. Land Degrad. Dev. 2013, 24, 277-286. [CrossRef]

19. Lyons, G.; Genc, Y. Commercial humates in agriculture: Real substance or smoke and mirrors? Agronomy 2016, 6, 50. [CrossRef]

20. Wang, D.Y.; Fonte, S.J.; Parikh, S.J.; Six, J.; Scow, K.M.; Liu, H. Biochar additions can enhance soil structure and the physical stabilization of $\mathrm{C}$ in aggregates. Geoderma 2017, 303, 110-117. [CrossRef]

21. Sojka, R.E.; Bjorneberg, D.L.; Entry, J.A.; Lentzl, R.D.; Orts, W.J. Polyacrylamide in agriculture and environmental land management. Adv. Agron. 2007, 92, 75-162. [CrossRef]

22. Mamedov, A.I.; Huang, C.; Aliev, F.A.; Levy, G.J. Aggregate stability and water retention near saturation characteristics as affected by soil texture, aggregate size and polyacrylamide application. Land Degrad. Dev. 2017, 28, 543-552. [CrossRef]

23. Sojka, R.E.; Entry, J.A.; Furhmann, J.J. The influence of high application rates of polyacrylamide on microbial metabolic potential in an agricultural soil. Appl. Soil Ecol. 2006, 32, 243-252. [CrossRef]

24. Ding, X.; Xu, G.; Zhou, W.; Kuruppu, M. Effect of synthetic and natural polymers on reducing bauxite residue dust pollution. Environ. Technol. 2020, 41, 556-565. [CrossRef] [PubMed]

25. Filippini, G. Environmental health criteria 49-Acrylamide. Ital. J. Neuro. Sci. 1986, 7, 171. [CrossRef]

26. Mroczek, E.; Kleiber, T.; Konieczny, P.; Waśkiewicz, A. Effect of residual monomer from polyacrylamide on head lettuce grown in peat substrate. Food Addit. Contam. Part A 2015, 32, 2113-2119. [CrossRef] [PubMed]

27. Watson, C.; Singh, Y.; Iqbal, T.; Knoblauch, C.; Simon, P.; Wichern, F. Short-term effects of polyacrylamide and dicyandiamide on $\mathrm{C}$ and $\mathrm{N}$ mineralization in a sandy loam soil. Soil Use Manag. 2016, 32, 127-136. [CrossRef]

28. Du, Z.-L.; Zhao, J.K.; Wang, Y.D.; Zhang, Q.-Z. Biochar addition drives soil aggregation and carbon sequestration in aggregate fractions from an intensive agricultural system. J. Soils Sediments 2017, 17, 581-589. [CrossRef]

29. Volikov, A.B.; Kholodov, V.A.; Kulikova, N.A.; Philippova, O.I.; Ponomarenko, S.A.; Lasareva, E.V.; Parfyonova, A.M.; Hatfield, K.; Perminova, I.V. Silanized humic substances act as hydrophobic modifiers of soil separates inducing formation of water-stable aggregates in soils. Catena 2016, 137, 229-236. [CrossRef]

30. IUSS Working Group WRB. World Reference Base for Soil Resources 2014, Update 2015. International Soil Classification System for Naming Soils and Creating Legends for Soil Maps. In World Soil Resources Reports; FAO: Rome, Italy, 2015; Volume 106, p. 138. 
31. Grant, P.G.; Lemke, S.L.; Dwyer, M.R.; Phillips, T.D. Modified Langmuir equation for S-shaped and multisite isotherm plots. Langmuir 1998, 14, 4292-4299. [CrossRef]

32. Shein, E.V.; Rusanov, A.M.; Nikolaeva, E.I.; Khaidapova, D.D. Parametric estimation of soil physical functions. Mosc. Univ. Soil Sci. Bull. 2007, 62, 101-106. [CrossRef]

33. Elliott, E.T. Aggregate structure and carbon, nitrogen, and phosphorus in native and cultivated soils. Soil Sci. Soc. Am. J. 1985, 50, 627-633. [CrossRef]

34. Amelung, W.; Zech, W. Minimization of organic matter disruption during particle-size fractionation of grassland epipedons. Geoderma 1999, 92, 73-85. [CrossRef]

35. Schmidt, M.W.I.; Rumpel, C.; Kögel-Knabner, I. Evaluation of an ultrasonic dispersion procedure to isolate primary organomineral complexes from soils. Eur. J. Soil Sci. 1999, 50, 87-94. [CrossRef]

36. Ryżak, M.; Bieganowski, A. Methodological aspects of determining soil particle-size distribution using the laser diffraction method. J. Plant. Nutr. Soil Sci. 2011, 174, 624-633. [CrossRef]

37. Amezkeka, E. Soil aggregate stability: A review. J. Sustain. Agric. 1999, 14, 83-151. [CrossRef]

38. Ananyeva, N.D.; Susyan, E.A.; Chernova, O.V.; Stephan, W. Microbial respiration activities of soils from different climatic regions of European Russia. Eur. J. Soil Biol. 2008, 44, 147-157. [CrossRef]

39. Kulikova, N.A.; Filippova, O.I.; Volikov, A.B.; Perminova, I.V. Slow nitrogen release from humic substances modified with aminoorganosilanes. J. Soils Sediments 2018, 18, 1400-1408. [CrossRef]

40. Klein, O.I.; Kulikova, N.A.; Stepanova, E.V.; Filippova, O.I.; Fedorova, T.V.; Maloshenok, L.G.; Filimonov, I.S.; Koroleva, O.V. Preparation and characterization of bioactive products obtained via the solubilization of brown coal by white rot fungi. Appl. Biochem. Microbiol. 2014, 50, 730-736. [CrossRef]

41. Mueller, L.; Shepherd, G.; Schindler, U.; Ball, B.C.; Munkholm, L.; Hennings, V.; Smolentseva, E.; Rukhovic, O.; Lukin, S.; Hui, C. Evaluation of soil structure in the framework of an overall soil quality rating. Soil Tillage Res. 2013, 127, 74-84. [CrossRef]

42. Beari, F.; Brand, M.; Jenkner, P.; Lehnert, R.; Metternich, H.J.; Monkiewicz, J.; Siesler, H.W. Organofunctional alkoxysilanes in dilute aqueous solution: New accounts on the dynamic structural mutability. J. Organometal. Chem. 2001, 625, 208-216. [CrossRef]

43. Volikov, A.B.; Ponomarenko, S.A.; Gutsche, A.; Nirschl, H.; Hatfield, K.; Perminova, I.V. Targeted design of water-based humic substances-silsesquioxane soft materials for nature-inspired remedial applications. RSC Adv. 2016, 6, 48222-48230. [CrossRef]

44. Gümüs, I.; Seker, C. Influence of humic acid applications on modulus of rupture, aggregate stability, electrical conductivity, carbon and nitrogen content of a crusting problem soil. Solid Earth 2015, 6, 1231-1236. [CrossRef]

45. David, M.B.; McIsaac, G.F.; Darmody, R.G.; Omonode, R.A. Long-term changes in Mollisol organic carbon and nitrogen. J. Environ. Qual. 2009, 38, 200-211. [CrossRef]

46. Volikov, A.B.; Ponomarenko, S.A.; Konstantinov, A.I.; Hatfield, K.; Perminova, I.V. Nature-like solution for removal of direct brown 1 azo dye from aqueous phase using humics-modified silica gel. Chemosphere 2016, 145, 83-88. [CrossRef] [PubMed]

47. Goebel, M.O.; Woche, S.K.; Bachmann, J.; Lamparter, A.; Fischer, W.R. Significance of wettability-induced changes in microscopic water distribution for soil organic matter decomposition. Soil Sci. Soc. Am. J. 2007, 71, 1593-1599. [CrossRef]

48. Plaza, I.; Ontiveros-Ortega, A.; Calero, J.; Aranda, V. Implication of zeta potential and surface free energy in the description of agricultural soil quality: Effect of different cations and humic acids on degraded soils. Soil Tillage Res. 2015, 146, 148-158. [CrossRef]

49. Piccolo, A.; Mbagwu, J.S.C. Effects of different organic waste amendments on soil microaggregates stability and molecular sizes of humic substances. Plant Soil 1990, 123, 27-37. [CrossRef]

50. Piccolo, A.; Mbagwu, J.S.C. Humic substances and surfactants effects on the stability of two tropical soils. Soil Sci. Soc. Am. J. 1994, 58, 950-955. [CrossRef]

51. Yamaguchi, T.; Takei, T.; Yazawa, Y.; Wong, M.T.F.; Gilkes, R.J.; Swift, R.S. Effect of humic acids, sodium, and calcium additions on the formation of water-stable aggregates in Western Australian wheat belt soil. Aust. J. Soil Res. 2004, 42, 435-439. [CrossRef]

52. Colazo, J.C.; Buschiazzo, D. The impact of agriculture on soil texture due to wind erosion. Land Degrad. Dev. 2015, 26, 62-70. [CrossRef]

53. Aimar, S.B.; Méndez, M.J.; Funk, R.; Buschiazzo, D.E. Soil properties related to potential particulate matter emissions (PM10) of sandy soils. Aeolian Res. 2012, 3, 437-443. [CrossRef]

54. Wang, X.; Chow, J.C.; Kohl, S.D.; Narasimh, L.; Yatavelli, R.; Percy, K.E.; Legge, A.H.; Watson, J.G. Wind erosion potential for fugitive dust sources in the Athabasca Oil Sands Region. Aeolian Res. 2015, 18, 121-134. [CrossRef]

55. Zhang, H.; Nie, W.; Wang, H.; Bao, Q.; Jin, H.; Liu, Y. Preparation and experimental dust suppression performance characterization of a novel guar gum-modification-based environmentally-friendly degradable dust suppressant. Powder Technol. 2018, 339, 314-325. [CrossRef]

56. Amato, F.; Karanasiou, A.; Cordoba, P.; Alastuey, A.; Moreno, T.; Lucarelli, F.; Nava, S.; Calzolai, G.; Querol, X. Effects of road dust suppressants on PM levels in a Mediterranean urban area. Environ. Sci. Technol. 2014, 48, 8069-8077. [CrossRef] [PubMed]

57. Liu, Y.; Nie, W.; Mu, Y.; Zhang, H.; Wang, H.; Jin, H.; Liu, Z. A synthesis and performance evaluation of a highly efficient ecological dust depressor based on the sodium lignosulfonate-acrylic acid graft copolymer. RSC Adv. 2018, 8, 11498-11508. [CrossRef]

58. Orlov, D.S.; Grishina, L.A. Practical Guide on Humic Chemistry; Lomonosov Moscow State University: Moscow, Russia, 1981; pp. 1-273. (In Russian)

59. Jiang, X.; Wright, A.L.; Wang, X.; Liang, F. Tillage-induced changes in fungal and bacterial biomass associated with soil aggregates: A long-term field study in a subtropical rice soil in China. Appl. Soil Ecol. 2011, 48, 168-173. [CrossRef] 
60. Milne, R.M.; Haynes, R.J. Comparative effects of annual and permanent dairy pastures on soil physical properties in the Tsitsikamma region of South Africa. Soil Use Manag. 2004, 20, 81-88. [CrossRef]

61. Gil, S.V.; Meriles, J.; Conforto, C.; Basanta, M.; Radl, V.; Hagn, A.; Schloter, M.; March, G.J. Response of soil microbial communities to different management practices in surface soils of a soybean agroecosystem in Argentina. Eur. J. Soil Biol. 2011, 47, 55-60. [CrossRef] 